\title{
Las palabras del año
}

\section{Words of the year}

\author{
Mónica Bejarano, MD., MSc., MACC (D)
}

Según un estudio de la Real Academia Española (RAE), entre las diez palabras que más dijimos en los países hispanohablantes en 2020 están cuarentena y pandemia, seguidas de coronavirus, confinamiento y contagio. Las otras cinco que completan esa lista fueron distanciamiento, mascarilla, teletrabajo, asintomático e incertidumbre.

Por el contrario, el Oxford English Dictionary no pudo escoger su tradicional palabra del año, porque consideraron que en el 2020 el lenguaje se adaptó «rápida y repetidamente» a un año sin precedentes, acumulando un nuevo vocabulario colectivo.

Lo ocurrido definitivamente fue inesperado y nos obligó a todos, en los diferentes escenarios en los que nos desenvolvemos, a hacer cambios. Como escribió Darwin en su libro El origen de las especies, publicado en I859, "las especies que sobreviven no son las más fuertes ni las más inteligentes, sino aquellas que se adaptan mejor al cambio".

Para la Revista Colombiana de Cirugía, el "cambio" que más nos impactó en el 2020 fue la ausencia del doctor José Félix Patiño Restrepo, fundador de la revista y editor por casi 20 años, por eso en este número, un año después de haber publicado su última contribución a la revista, como muestra del respeto y admiración que sentimos todos los que lo conocimos en persona o a través de sus obras, queremos hacer un homenaje compartiendo una de las cartas que recibimos en su momento.

Este año también va a ser especial, pero de manera diferente, porque en mayo llegamos a los primeros 35 años de nuestra revista, con una emisión trimestral ininterrumpida, "publicando colaboraciones originales sobre temas de cirugía general y de interés para toda la profesión médica, incluso los de carácter humanístico, socioeconómico y los referentes a la educación médica". Por eso, deseo empezar a construir mi lista de palabras para este año, con la que espero que se sientan representados.

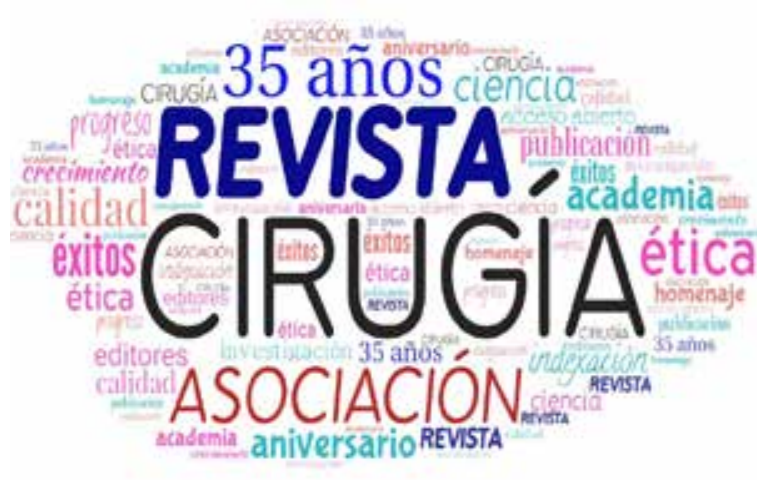

Palabras clave: revista; políticas editoriales; indización y redacción de resúmenes; cirugía general; investigación; pandemias.

Keywords: journal; editorial policies; abstracting and indexing; general surgery; research; pandemics.

Fecha de recibido: diciembre 18 de 2020 - Fecha de aceptación: diciembre 21 de 2020

Correspondencia: Mónica Bejarano, MD., MSc., MACC. Carrera 59 \# 11B-56, Cali, Colombia. Teléfono: 3155574039

Dirección electrónica: monicirugia@gmail.com

Citar como: Bejarano M. Las palabras del año. Rev Colomb Cir. 2021;36:17. https://doi.org/10.30944/20117582.862

Este es un artículo de acceso abierto bajo una Licencia Creative Commons - BY-NC-ND https://creativecommons.org/licenses/by-nc-nd/4.0/deed.es 